\title{
Performance Analysis Of Joint Venture-Owned Enterprises (Badan Usaha Milik Desa/Bumdes) Leles Sub District, Garut
}

\author{
Nina Karlina \\ Center for Policy Studies and Public Service \\ School of Social and Political Sciences, \\ Padjadjaran University \\ karlina_nina@yahoo.com
}

\author{
Imanudin Kudus \\ Center for Policy Studies and Public Service \\ School of Social and Political Sciences, \\ Padjadjaran University \\ iman.fisipunpad@gmail.com
}

\begin{abstract}
BUMDes in Leles Sub-district Garut District aims to help the economy of its people by focusing on trade services, trade in goods, savings and loans, and management of village markets. The advantages of Joint venture-Owned Enterprises(BUMDes) Leles has been established cooperation with PT. Changsin Reksa Jaya located in the Sub-district of Leles in the procurement of catering, bureaus and services. BUMDes Together with Leles get a lot of praise even become a pilot of Joint venture Owned Enterprises (BUMDes). But many parties are doubting the independence of this BUMDes when working with PT. Changsin Reksa Jaya stalled. The purpose of this research is to create an ideal management model for BUMDes with Leles sub-district. But before entering that stage, actually in advance we have to understand the performance of this BUMDes itself.
\end{abstract}

This research is conducted on the performance aspect achieved, so that the researcher use quantitative design. This design is supported by frame of reference (FOR) to observe and read records recorded through research instruments. The design of this study is a survey as an attempt to collect information from respondents by using questionnaires. "The research tool is used to test the answer of rational respondents, so it can explain the phenomenon of the problem." Of the four dimensions Balance scorecard which the results of research indicate that the Financial perspective, Customer perspective Internal business process perspective and Learning and growth shows in the category quite well, Even financial perspective quite high, but the profit of BUMDes wasn't felt by the surrounding community, whereas the purpose formed BUMDes to improve socio-economic community not just the board only. The lowest is learning and growth, this is because the competence of the chairman and board of BUMDes not in accordance with the expected, especially in financial management. So that the excavation of the potential of the village becomes very important so that the training will be done on target.

Keywords-performance, analysis performance, BUMDes

\section{INTRODUCTION}

BUMDes in Garut District newly established about 157 BUMDes, spread in 42 sub-districts but only about 21 districts that have owned BUMDes and total Village in Garut district around 424 villages and only 157 villages that have BUMDes, based on the mandate of Local Regulation No. 24 of 2011 on the procedures Establishment and management of village-owned enterprises every village in Garut district must have a Business Entity considering the importance of BUMDes as a milestone of economic growth of the village.

From all of BUMDes in Garut District, BUMdes subdistrict Leles is a joint venture owned enterprises which is the flagship of Garut district. BUMDes sub-district Leles is abBUMdes which get an award from government.

In the sub-district of Leles Garut district aims to help the economy of its people by focusing on trade in services, trade in goods, savings and loans, and management of village markets. The advantages of BUMDes Together Leles has been established cooperation with PT. Changsin Reksa Jaya located in the District of Leles in the procurement of catering, bureaus and services. Joint venture Owned enterprises of Leles get a lot of praise even become a pilot BUMDes.

Based on result observations BUMDes of Leles subdistrict considered good because of its cooperation with PT.Changsin Reksa Jaya. This company orders food for all its employees three times a day, so the profit of BUMDes is increasing. However, based on the results of observation Joint venture Owned Enterprise have not been able to provide additional PAD to the villages in the sub-district of Leles, and the ability of BUMdes is still very weak to stand alone when PT. Changsin Reksa Jaya does not give job order to this BUMDes.

Other problems seen in the Joint venture owned Enterprises throughout the sub-district of Leles are:

1. The problems is, BUMDes has not been able to develop the local economy of this village due to the formation of BUMDEs is not based on the needs, potential and capacity of the village, in the capital participation of the village government in the form of financing and village wealth, the village has not fully able to provide capital to BUMDes

2. Village deliberation must be aligned between the business field of BUMDes with the purpose of BUMDes 
so that between business and objectives BUMDes can be integrated.

3. BUMDes, hasn't been able to comprehensively assess the potential of villages (natural resources, human resources, and artificial resources) to open space for new business units that allow for greater and more open employment opportunities for marginalized community groups. BUMDes yet can initiate and encourage the community, to create a competitive advantage village, so that created one village one product. Creation of competitive advantage based on (i) production differentiation; (Ii) low cost of production; And (iii) rapid response to change and innovation needs.

4. less informative BUMDes management to the community about the type of business, and BUMDes activities. In the community's opinion, BUMDes belongs to the Village Government

5. The existence of BUMDes should be employment and economic access for the community in the village. But some people judge if BUMDes has not empowered the community. Managers BUMDes not through the recruitment process that managers BUMDes average there are problems in managerial. Yet this is very important related to the value of assets, turnover, and institutional accountability of BUMDes

Started from the above problem, although BUMDes on sub-district Leles is already favored but many parties who doubt this joint BUMDes can be independent if apart from PT Changsin, so it is necessary to measure the performance of this joint BUMDes so that the future can be prepared everything to support BUMDes together Which is selfsufficient.

\section{LITERATURE REVIEW}

Kaplan and Norton (2001) state that nonprofit and governmental organizations generally have significant difficulties in defining their strategies clearly. Most nonprofits and governments have difficulties with the original Balance Scorecard architecture, where financial perspectives are placed above the hierarchy, since obtaining financial gain is not the main objective for most organizations, the architecture can be reset so that it places the customer or constituent in the top hierarchy.
Chart 2.1.Adapting the Balance Scorecard Framework to Nonprofit and Public Organization

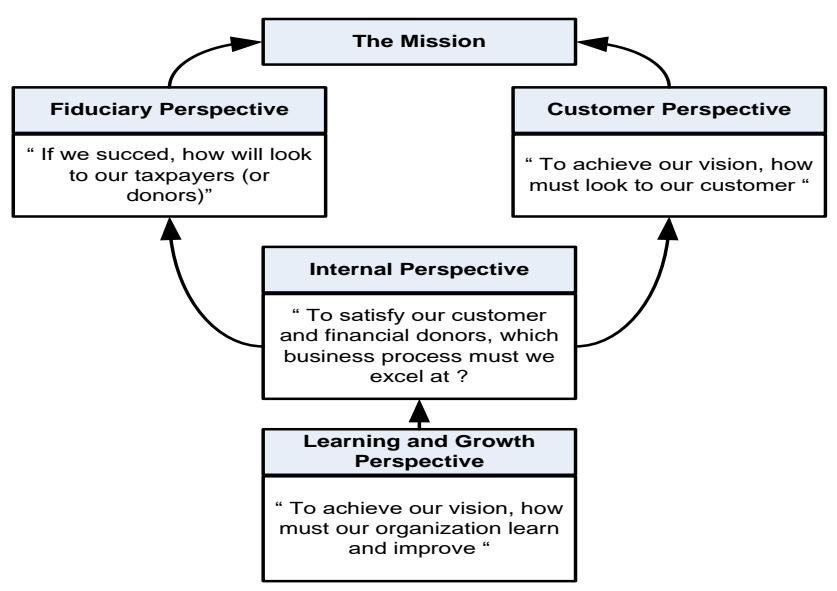

The Balanced Scorecard for the public sector helps the organization's efforts in developing and implementing program and service strategies to carry out the mission. Organizations typically use the BSC to communicate mission and strategy to all employees to measure the success of the programs and services provided, and to undertake assessments of the changes that the organization needs to make to improve the efficiency and effectiveness of the program. The performance scorecard is part of the management's management agenda, and is used to track the progress of an organization's programs and services.

Balance scorecard for public sector is a comprehensive perspective to measure performance appropriately in public sector organization. Where profit (profit) is not a major booster for public sector organizations. Norton and Kaplan made adjustments to the existing perspectives of the BSC. In the BSC for the public sector, the mission replaces financial results as the ultimate goal of public sector organizations and is supported by three other important perspectives namely cost, benefits, and legitimizing authorities.

In the Balance Scorecard for the public sector in question Cost perspective is financial cost and social cost. Unlike in profit-oriented organizations that are always measured with financial, organizations in the public sector usually benefit the size of the implementation of programs and policies in value with positive and negative. The legitimizing authority perspective on the BSC changes the customer's perspective. 
Chart2.2 The five perspective of the Public sector Scorecard

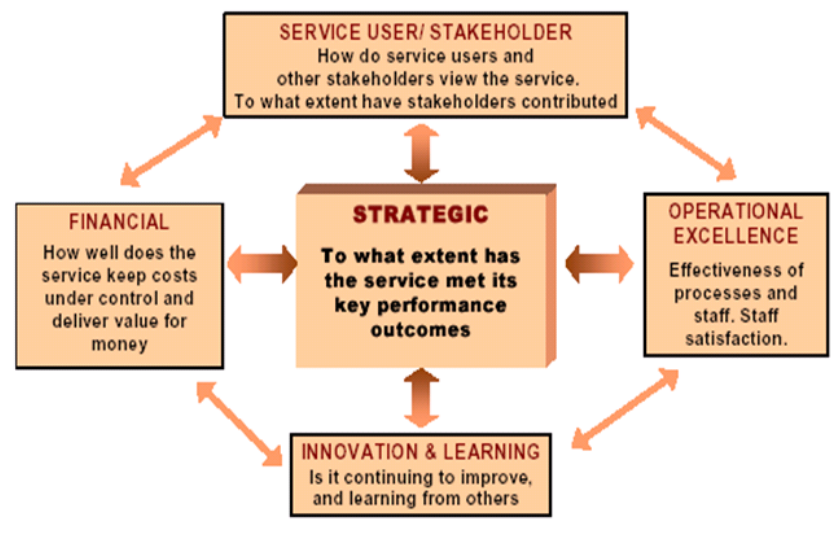

Judging from the conditions above Kaplan \& Norton's Balanced Scorecard measurement model is well suited for this study where all the above theoretical schemes discussing performance are in Kaplan \& Norton's Balanced Scorecard scheme. That the Kaplan \& Norton Balance Scorecard's measurement framework (1996: 95) uses four perspectives with a starting point with a strategy as the basis for the peracangannya. The four perspectives of organizational performance include:

1. Financial perspective

2. Customer perspective

3. Internal business process perspective

4. Learning and growth

\section{RESEARCH METHODS}

This research is conducted on the performance aspect achieved, so that the researcher use quantitative design. This design is supported by frame of reference (FOR) to observe and read records recorded through research instruments. The design of this study is a survey as an attempt to collect information from respondents by using questionnaires. "This research tool is used to test the responses of rational respondents, so as to explain the phenomenon of the problem" (Miller, 1983: 211). In addition the survey method is used extensively and deeply to the object under study, not only explaining the empirical facts encountered in the field but also performing the analysis of the performance of the company's services.
Table; 3.1. Variable Operationalization

\begin{tabular}{|c|c|c|}
\hline \multirow[t]{3}{*}{$\begin{array}{l}\text { Organizational } \\
\text { Performance }\end{array}$} & 1. Financial & $\begin{array}{l}\text { 1. The added value of the economy } \\
\text { is increasing. } \\
\text { 2. Increased corporate earnings. } \\
\text { 3. Utilization of company activity } \\
\text { takes into account the decline in } \\
\text { its value. } \\
\text { 4. Reduced company costs } \\
\text { 5. significantly (cost effectiveness) } \\
\text { 6. The calculation of economic } \\
\text { added values progresses } \\
\text { 7. Increased percentage of employee } \\
\text { income } \\
\text { 8. Increase the percentage of } \\
\text { corporate earnings } \\
\text { 9. Increased earning per share } \\
\text { 10. Increased net income } \\
\text { 11. Increased net profit margin } \\
\text { 12. An increase in the operating cost } \\
\text { to sales ratio } \\
\text { 13. Increase return on Asset } \\
\text { 14. Achieving the target return on } \\
\text { Asset }\end{array}$ \\
\hline & 2. Customer & $\begin{array}{l}\text { 1. There is an increasing number of } \\
\text { new consumers. } \\
\text { 2. Decrease in the number of } \\
\text { consumers who quit / exit. } \\
\text { 3. Customer loyalty to the company } \\
\text { 4. The speed of service time. } \\
\text { 5. The level of customer satisfaction } \\
\text { increases. } \\
\text { 6. Positive result of customer } \\
\text { satisfaction index survey } \\
\text { 7. Social activities with customers } \\
\text { 8. Positive result of customer } \\
\text { relationship index survey } \\
\text { 9. Quality of product quality } \\
\text { produced by company } \\
\text { 10. Increased percentage of product } \\
\text { sales } \\
\text { 11. Benefits and benefits customers } \\
\text { feel } \\
\text { 12. Decrease in the number of } \\
\text { customer complaints }\end{array}$ \\
\hline & $\begin{array}{l}\text { 3. Internal } \\
\text { Process }\end{array}$ & 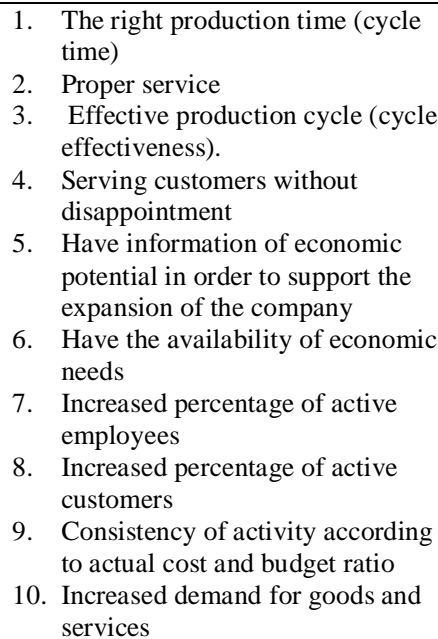 \\
\hline
\end{tabular}


Table; 3.1., cont.

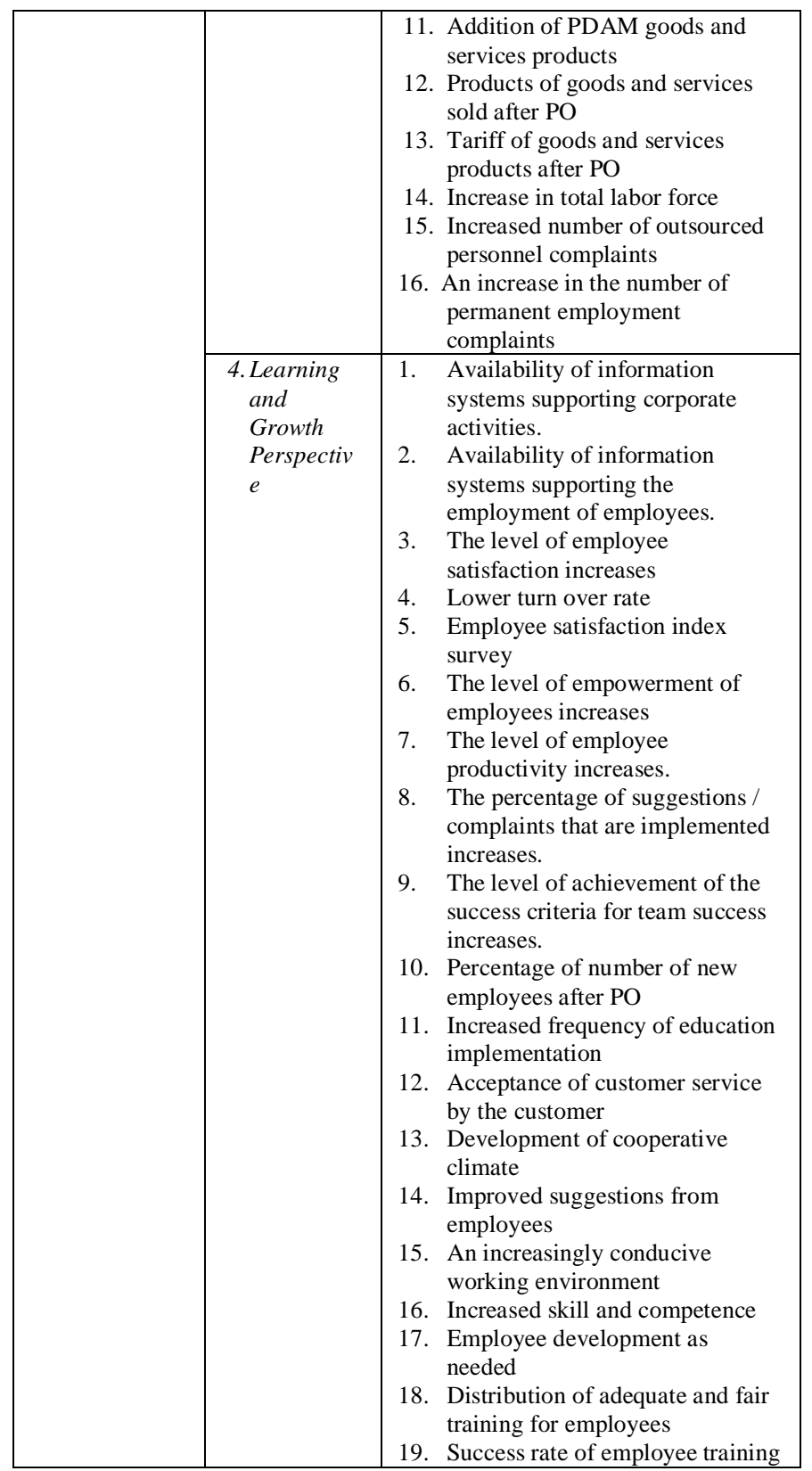

\section{ANALYSIS AND DISCUSSION}

Graph 4.1. Perceptions of Respondents On Financial Dimensions

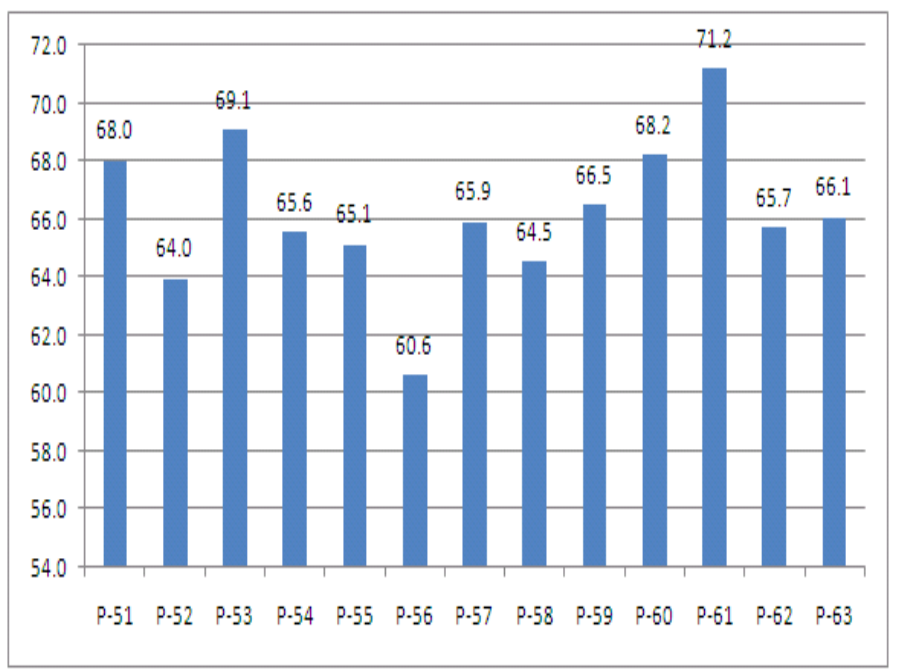

Source: Result of Research, 2017

In general, the performance of BUMDes from a financial perspective is good enough, but based on the results of interviews and observation of the results of BUMDes profit has not reached the improvement of living standards of people around sub-district Leles, even haven't change the social economy of the community sub-district Leles. The participation of BUMDes together in improving PAD of Leles sub-district is not yet optimal.

Graph 4.2. Respondent's Perception On Customer Dimension

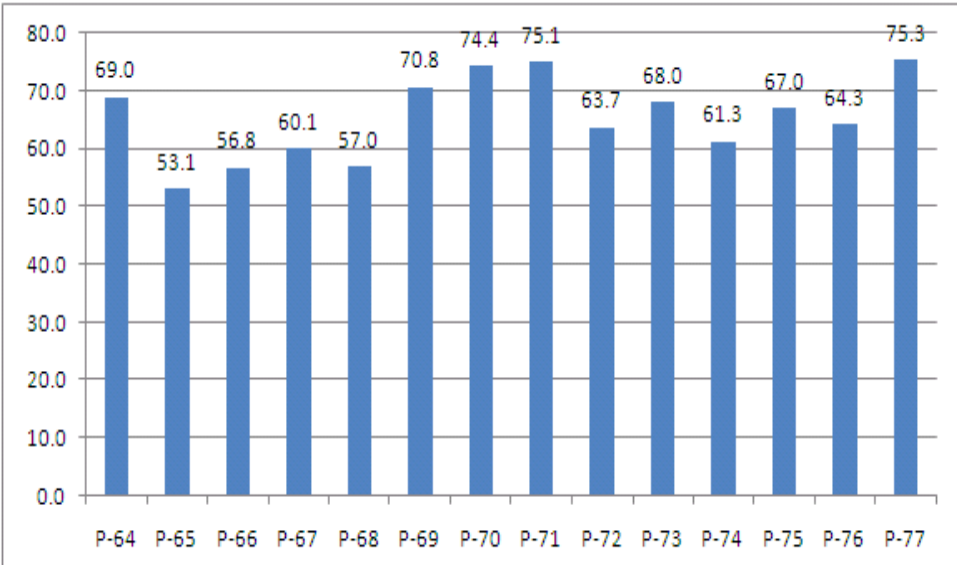

Source: Result of Research, 2017

The survey results of customer confidence index, the majority of respondents assess the level of customer trust in Joint Venture Owned Enterprises relatively high. PT Changsin is a loyal customer from BUMDes start up until now, but the addition of customer can not be done because of lack of promotion from the administrators. Why the result is high because only have single customer with big enough order value. This makes the BUMDes feel no longer need to look for other customers. And become dependent on PT Changsin. 
Graph 4.3 Perceptions of Respondents On Internal Process Dimensions

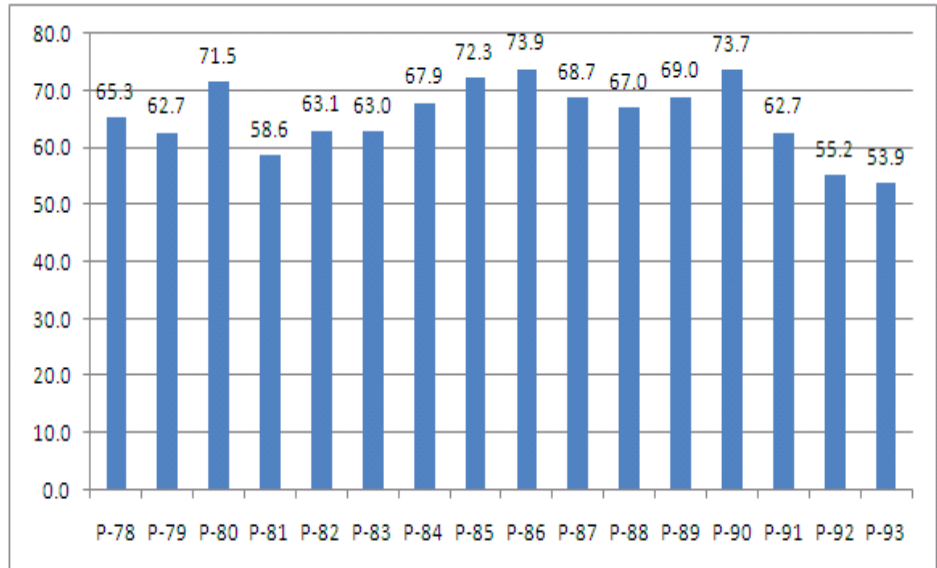

Source: Result of Research, 2017

Generally viewed from the perspective of the process, the performance of Joint Venture Owned Enterprises has been considered good enough. Nevertheless, there are still some points that must be considered by PDAM Bandung related to the perspective of this process that is 1) Number of complaints from workers who are increasing because welfare does not increase. 2) The number of complaints from the community that most do not feel the impact of this joint BUMDes and 3) Based on the data ratio of customers and employees are not comparable. Customers only one is one company, whereas BUMDes should be able to expand its business is not monotonous only the provision of food for workers in PT Chingsan only.

Graph 4.4. Respondents' Perceptions on Learning and Growth Dimensions

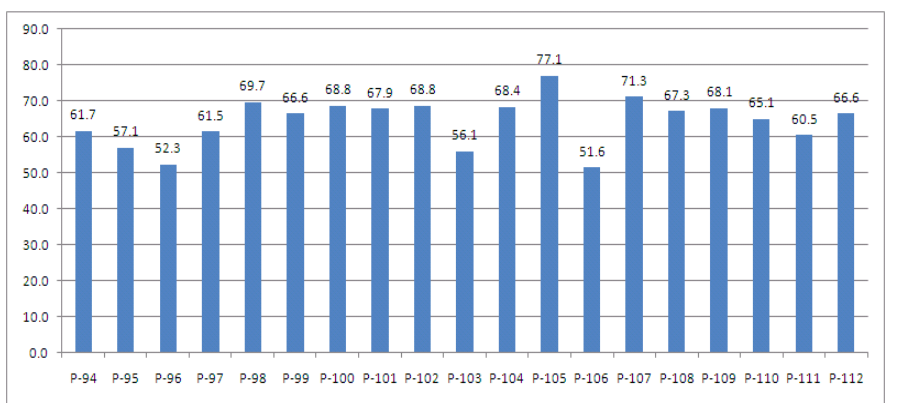

Source: Result of Research, 2017

In general the performance of Joint venture Owned Enterprises viewed from the aspect of learning and growth perspective shows the performance of PDAM Bandung is good enough. But some things should be more concerned by PDAM Bandung related to the learning and growth perspective which is 1). The cooperation is not progressive cooperation, 2) the satisfaction of employees and the surrounding community that still needs to be improved, 3) less competitor's competence, and 4) .BUMDes has not optimized the utilization of information systems in support of employment, 5) Leadership is still collegial.
Graph 4.5 Accumulation of Respondents Perception on BUMDes Performance

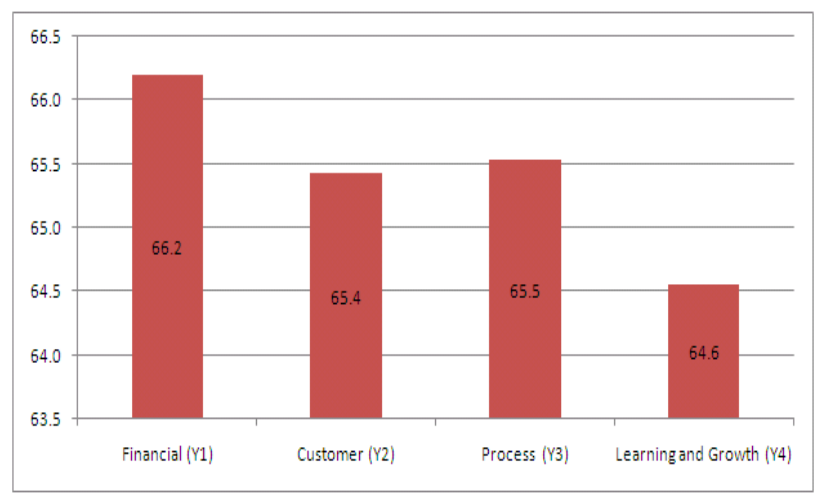

One of the four dimensions used to measure performance variables, the financial perspective dimension that has the highest score but not significantly different with other dimensions. While the lowest score is the dimension of learning and growth.

\section{CONCLUSIONS AND SUGGESTIONS}

From the four dimensions of Balance scorecard is Financial perspective, Customer perspective Internal business process perspective and Learning and growth is actually not lacking, even financial perspective is high, but BUMDes profit is not felt by the surrounding community, whereas the purpose is formed BUMDes to improve socioeconomic community Just the board only. The lowest is learning and growth, this is because the competence of the chairman and board of BUMDes not in accordance with the expected, especially in financial management. So that the excavation of the potential of the village becomes very important so that the training will be done on target.

\section{REFERENCES}

[1] Athoillah, Anton. 2010. Dasar-Dasar Manajemen. Bandung: Pustaka Setia.

[2] Antlov Hans, 2003, Negara dalam Desa Patronase Kepemimpinan Lokal, Lappera Pustaka Utama

[3] Babbie, E. 1983. The Practice of Social Research. California:Wads Worth Publishing Company Belmont

[4] Creswell, John W. 1993. Research Design Pendekatan Penelitian Kualitatif, Kuantitatif, dan Mixed. Yogyakarta: Pustaka Pelajar. Penterjemah Achmad Fawaid.

[5] Dunn, William N. 1999. Analisis Kebijakan Publik. Yogjakarta: Gadjah Mada University Press.

[6] Dye, Thomas R.1995. Understanding Public Policy. New Jersey: Prentice Hall..

[7] Effendi, Tadjuddin Noer. 1993. Sumber Daya Manusia Peluang Kerja dan Kemiskinan. Yogyakarta:Tiara Wacana

[8] Hardjanto, Imam, (2006) Pembangunan KapasitasLokal (Local Capacity Building). Malang: Program PascasarjanaUniversitasBrawijaya.

[9] Koncoroningrat, 1988, ManusiadanKebudayaan di Indonesia, Djambatan

[10] Mustopadidjaja. 2003. Manajemen Proses Kebijakan Publik. Jakarta: LAN. 
[11] Nigro, F, A. and Loyd G. N. 1990. Modern Public Administration. New York:Harper and Row

[12] Pal, L. 1996.Public Policy Analysis an Introduction. New York:Nilson Antonio

[13] Riant, Nugroho. 2003. Kebijakan Publik Formulasi, Implementasi, dan Evaluasi. Jakarta: Elex media Komputindo.

[14] S, Arikunto. 1996. Prosedur Penelitian: Suatu Pendekatan Praktek. Jakarta: Bina Aksara.

[15] S, Danim. 1997. Studi Penelitian Kebijakan. Jakarta:Penerbit Bumi Aksara.

[16] S, Prawirosentono. 1999. Kebijakan Kinerja Karyawan. Yogyakarta: BPFE UGM.

[17] Uma, S. 1992. Research Methods for Business: A Skill Building Approach: 2nd Edition. Singapore: John Wiley \& Sons Inc.

[18] Wheelen, T, L. and J. David H. 1992. Strategic Management and Bussiness Policy. Addison Wesly Publishing Company. Massachussetts.

[19] ---------.(2001). Manajemen Strategis. Alih Bahasa : Julianto Agung. Yogyakarta: Andi.

[20] W.J.S. Poerwadarminta. 1995. Kamus Umum Bahasa Indonesia. Jakarta: Balai Pustaka.

[21] Regulation of the Minister of Village, Development of Disadvantaged Regions, and Transmigration of the Republic of Indonesia Number 4 Year 2015 on Establishment, Management and Management, and Dissolution of Village Owned Enterprises

[22] Law No. 6 of 2014 on Villages.

[23] Regional Regulation of Garut Regency 24 of 2011 on Village Owned Enterprises. Garut, Garut regency.

[24] Regulation of the Minister of Home Affairs Number 39 of 2010 concerning Village Owned Enterprises (c.2). Jakarta, Minister of Home Affairs.

[25] Government Regulation Number 72 Year 2005 regarding Village. Jakarta, Directorate General of Regional Autonomy.

[26] Law Number 32 Year 2004 regarding Regional Government. Jakarta, Director General of Regional Autonomy 